Article

\title{
Consumers' Purchasing Intentions on the Legume Market as Evidence of Sustainable Behaviour
}

\author{
Magdalena Śmiglak-Krajewska ${ }^{1}$ (D) Julia Wojciechowska-Solis ${ }^{2, *}{ }^{\mathbb{C}}$ and Domenico Viti ${ }^{3}$ \\ 1 Department of Finance and Accounting, Faculty of Economics, Poznan University of Life Sciences, \\ Wojska Polskiego 28, 60-637 Poznań, Poland; smiglak@up.poznan.pl \\ 2 Department of Agritourism and Rural Development, Faculty of Agrobioengineering, \\ University of Life Sciences in Lublin, Akademicka 13, 20-950 Lublin, Poland \\ 3 Department of Law, University of Foggia, Via A. Gramsci 89/91, 71100 Foggia, Italy; domenico.viti@unifg.it \\ * Correspondence: julia.wojciechowska@up.lublin.pl; Tel.: +48-81-445-60-10
}

Received: 7 August 2020; Accepted: 20 September 2020; Published: 23 September 2020

check for updates

\begin{abstract}
The purpose of this paper is to verify the knowledge that is useful for legume producers in relation to consumers' eating habits in the field of legume products. According to experts, leguminous products have a positive effect on human health. The tendency towards healthy eating habits is also associated with the idea of sustainable consumption. The authors have attempted to combine these two trends. The main goal was to determine, among consumers, the level of knowledge about legumes, product purchase motives, and preferred places of purchase. This study was carried out with the use of an authorial questionnaire. In total, 1067 respondents from all regions of Poland participated in the study. The Statistica 13.1PL programme was used for statistical analyses. Methods used: descriptive statistics, discriminant analysis and linear regression analysis. With the aid of the conducted analyses, it was possible to determine that peas, beans, soybeans and lentils are the most recognised and most frequently consumed products (in various configurations) among the residents of the studied groups. The most important motives for their purchase among the surveyed consumers were "flavour", "price" and the fact that these products can be an alternative to meat products and contain a lot of protein and fibre. The purchase channels that legume product producers must pay attention to are large-area shops and online sales. Sustainable consumption awareness for the consumers of legume products is best defined by a variable in the regression equation-" no harmful substances used during its production". The legume products market has not yet flourished in Poland. The products are an excellent alternative to meat products due to their high protein content. Pro-health education has a measurable effect and consumer awareness is growing. Producers should use this knowledge by emphasising, in the promotion of products, that the products are produced in accordance with the idea of sustainable development, without the use of harmful substances, and that no means are used to extend the shelf life.
\end{abstract}

Keywords: consumer awareness; consumer behaviour; environmental awareness; food choice; legume; purchase motives; place of purchase; sustainable foods

\section{Introduction}

\subsection{Theory and Background}

Currently, there are almost 7.6 billion people living in the world. The population increases each year by an additional 83 million. According to the United Nations forecasts, the population will reach eight billion in 2023 and 10 billion in 2056 [1]. Meeting the world's food needs at such a level will therefore increase food production by at least $40 \%$. Such an increase is possible, but it can be 
realised by $80 \%$ through increased plant production. One of the best alternatives to meat are legume seeds, which are a valuable source of vegetable protein. Thanks to their beneficial influence on the environment and their nutritional and health benefits, they are called "superfoods" and the protein of the future, and the promotion of their wider use is carried out in campaigns on a global scale [2-6]. They are also a good source of minerals such as calcium, phosphorus, potassium, magnesium, iron and $B$ vitamins $[7,8]$. It is suggested that people limit the amount of meat in their diet and increase their consumption of legume seeds. This is extremely important in terms of reducing the amount of saturated fatty acids that can cause many serious diseases when consumed in excess. The use of legumes in nutrition is therefore consistent with the sustainable consumption model.

Currently, about $42 \%$ of the protein consumed in the EU (European Union) is derived from plants and the remaining $58 \%$ is derived from animals (meat, fish, eggs and dairy products). Responding to its growing consumption among the world's population, industrial meat production exerts a huge negative influence over the environment through the amount of greenhouse gases produced, among other things. A nutrition model with a low meat content, based on plant-derived products, has been proven to have a lower negative impact on the environment [4-6]. In the scenario modelled by the European Commission, diets will gradually change over the next ten years to a 50/50 ratio. Consumers will continue to consume the same quantity of calories, proteins and fats. It would lead to a $17 \%$ decrease in animal protein consumption. When it comes to the impact on the environment forecast by the European Commission, the EU's carbon footprint would decrease by $6 \%$ (22 million tons $\mathrm{CO}_{2}$ equivalent) in 2030 [9].

Guidelines for increasing the consumption of legumes are justified not only by nutritional but also by socio-economic and environmental reasons. The cultivation of those plants is much cheaper than the production of meat, especially when it comes to water and soil efficiency, and it also helps to reduce the emission of greenhouse gases [10].

Legume cultivation, due to its characteristics, also endorses sustainable agriculture. These plants are one of the best forecrops for other arable crops because they significantly improve physical properties and soil fertility and enrich it with nitrogen [11-14]. Nitrogen is the main component of protein and an essential nutrient for plants. Legumes supply 139-170 million tons of nitrogen to the global nitrogen cycle every year, while the world production of nitrogen fertilisers in 2019 amounted to 119.61 million tons $[8,9,15]$. They also contribute to the improvement of water and air relations in the soil [16-18]. Introducing these plants to crop rotation allows farmers to limit the use of mineral fertilisers, which has both an ecological and an economic aspect [19]. Field experiments and studies at farms have shown that nitrogen fertilisation rates for legume cover crops can be reduced by $20-35 \mathrm{~kg}$ $\mathrm{N}$ per hectare (ha) without affecting yield level $[20,21]$. The cultivation of legume seeds contributes to reducing the greenhouse gases production, and in a global approach it also endorses the population nutrition and improves the economic situation of many households [22]. Those plants also play an indisputable role in crop rotation, especially on organic farms, interrupting the frequent sowing of successive crops, especially the ones contributing to a high rotation. They contribute to an increase in the yields of successive plants, especially cereals and rapeseed. It directly translates into an effortless increase in the yield of the successive plants by up to 0.5 to $1 \mathrm{t} / \mathrm{ha}[20,23]$. The inclusion of legumes in a long-term crop rotation system has a positive impact on soil conditions. Carbon that is present in the soil is crucial for the carbon cycle, soil fertility and plant growth, and therefore it plays a vital role in global climate models and agricultural systems [24]. Recent research conducted by Professor Adams indicates that legumes are not as dependent on water as other crops. He claims that, on a hot day, legumes can close their stomata and save some water [25]. Most legumes are also very attractive for bees and often act as a shelter for other wildlife. Therefore, they can have a positive impact on biodiversity in low-input farming systems [24].

The use of legumes for food purposes prevails in the world. Among the species (with the exception of soybeans), the most important in terms of cultivation area in the world are beans $(41.4 \%$ of the cultivation area) and chickpeas (16.5\%). The area of legumes sown for seeds in the world has 
remained at a similar level for several years and ranged from 61 to 70 million ha. After the year 2010, there occurred a visible increase in the area of cultivation. In 2017, 95 million ha was sown with legumes worldwide, which constituted over 50\% more than in 1980 and 30\% more than in 2010. In the European Union, most legume seeds are harvested in France, i.e., over 800 thousand tons. Poland ranks fourth (624 thousand tons), after Great Britain (743 thousand tons) and Lithuania (710 thousand tons), among the legume producers in the European Union. The biggest area among the EU countries sown by legumes belongs to Spain $(521,386 \mathrm{ha})$; the second belongs to Poland $(316,208 \mathrm{ha})[26,27]$.

Growing legumes promotes biodiversity and creates a more diverse landscape for animals and insects. It also reduces the risk connected to climate and market fluctuations, to which farmers are exposed. It has also been observed to be of strategic importance for the global economy, as economic benefits lead to more sustainable farming systems and improved food security [28].

The aim of this study was to verify the knowledge and determine consumers' propensity to consume, as well as to identify attitudes towards purchasing, legume products.

\subsection{The Essence of Sustainable Consumption}

On a global scale, the challenge of sustainable development is becoming increasingly important. Its main component is the sustainable consumption of various goods $[29,30]$. Sustainable consumption, as a relatively new economic category, has not yet been clearly defined [31]. The source literature lacks definition coherence as well as terminology coherence concerning sustainable consumption [32,33]. Authors provide different definitions, but these are reduced to the same understanding of the idea of sustainable consumption. According to Bylok [34], consumption is sustainable when it simultaneously takes care of the population's needs for present and future generations. Wasilik [35], on the other hand, when writing about sustainable consumption, stresses that it is part of the idea of sustainable development, i.e., development that seeks to improve the quality of life while maintaining social equality, biodiversity and the abundance of natural resources. The point is that, while striving for a good life, we should not destroy nature, on which depends life on Earth, not exhaust all the natural resources, which results in a lack of them for people living here in the future, nor condemn others to poverty while striving to improve the quality of our own lives [36].

The foundation of the modern sustainable consumption policy constitutes Agenda 21, a document adopted as part of the 1992 Rio Declaration on Environment and Development (Agenda 21). The idea of sustainable consumption first appeared in principle 8 of the principles on general rights and responsibilities of the 1992 Rio Declaration on Environment and Development. According to this principle, in order to achieve sustainable development and a higher quality of life for all people, states should reduce and eliminate unsustainable patterns of production and consumption and promote appropriate demographic policies. This principle is expanded in Chapter 4 of Agenda 21, the final document of Rio de Janeiro. The very title of this chapter, Changing Consumption Patterns, indicates the need to change the present consumption policy. It was stressed that sustainable consumption is linked to an assessment of the degree of use of the natural resources on a global scale, the degree of economic and civilisational development of a country or region, and environmental protection principles [37-40].

According to the FAO definition, sustainable food consumption is a method of nutrition that has a low environmental impact and therefore contributes to food security and the good health of the present and future generations. A sustainable diet protects and respects biodiversity and ecosystems, is culturally acceptable, economically accessible to all population groups and nutritionally appropriate, and is also safe and healthy, while optimising natural and human resources [41,42]. Consumer decisions in this approach to nutrition should be made by taking into account social responsibility (for the environment), although the basic determinants of choice should not be ignored; they include, mainly, the needs, the preferences and the possibilities of their realisation [43].

The essence of the sustainable consumption was presented in the project Responder (the seventh EU Framework Programme). It presents two approaches to sustainable consumption. In a narrow sense, it was defined as efficient, effective consumption, i.e., reducing resource consumption, and thus 
the overall amount of pollution and waste, while, in a broad sense, it was defined as a better quality of life, including health improvements, with reduced consumption of environmental resources [44]. The European Commission determined, in the document Roadmap to a Resource Efficient Europe, on 20 September 2011, the goals and challenges facing sustainable consumption. The main goal concerning sustainable consumption and production within the scope of product improvement and consumption pattern change is defined as follows: by 2020, citizens and public authorities have the right incentives to choose the most resource efficient products and services, through appropriate price signals and clear environmental information. Their purchasing choices will stimulate companies to innovate and to supply more resource-efficient goods and services. Until then, minimum environmental performance standards are set to remove the least resource efficient and most polluting products from the market. Consumer demand is high for more sustainable products and services [45].

Some authors identify sustainable consumption with eco-consumption, also called green consumption [46-52]. According to this trend, the keys to the goal of sustainable development are changes in the consumption area: "This is not about reducing consumption, but about modifying it in such a way that its external negative effects would be as small as possible". According to Władysława Łuczka [32], the concept of sustainable consumption presented by these authors is considered in a narrow sense, emphasising only its ecological aspects and giving less significance to the other two aspects of sustainable development to which she refers, namely economic and social ones.

A broader perspective on sustainable consumption is presented by Kramer [53]. She shows that sustainable consumption combines a range of social, economic and political practices at the individual, household, community, business community and government levels with the aim of:

- reducing the direct environmental effects on the production processes, use and disposal of goods and services;

- providing everyone with the chance to meet the basic consumption needs related to key goods and services such as food, water, health protection, education and shelter;

- increasing the opportunities for sustainable development in the southern countries;

- developing the consumption of goods and services that have a positive influence on the health and wellbeing of women and children;

- developing and using energy- and water-saving devices;

- developing public transport and pro-ecological transport, developing ecological goods and services adapted to the global requirements for environmental protection;

- promoting lifestyles that place a greater emphasis on social cohesion, local traditions and intangible assets.

According to Kiełczewski [54], it should be remembered that sustainable consumption is not only a matter of balancing consumption and the natural environment, as it is also conditioned by social reasons. Sustainable consumption is therefore sustainable in the following aspects:

- economic: the effective ratio between current and future consumption is established, so that the consumption processes do not contribute to significant economic imbalances;

- ecological: consumption usefulness is maximised while simultaneously maintaining the usefulness and quality of natural resources and the environment, enabling direct consumption of environmental goods; the material level of consumption is adapted to the requirements of circular economy functions, which are equivalent to the demand that favours forms of consumption that are as minimally troublesome for the environment as possible;

- social: consumption is relatively evenly distributed, i.e., it is accessible to all people regardless of time and space, at least in terms of socially desirable goods; the social sustainability of consumption also means the demand that favours forms of consumption that cause as few social problems as possible or contribute to solving them, for example, by generating new jobs and increasing cultural diversity; 
- psychological: consumption processes contribute to an increase in the quality of life, i.e., to establishing an optimal balance between material consumption and meeting intangible needs;

- demographic: demographic conditions do not constitute a permanent obstacle to consumption growth; life expectancy increases, consumer health improves, and membership to a demographic or socio-professional group does not constitute a significant obstacle to the consumption of socially desirable goods;

- $\quad$ spatial: the ways in which these needs are met do not break the rules of spatial order.

According to Górka [55], the interest in the phenomenon of sustainable consumption results mainly from the problem of increasing inequalities between the consumption of resources and the availability of these resources on the Earth, as well as different living standards of societies living in countries with a diversified growth. Our planet's natural resources are not permanent, and not all of them are renewable. Therefore, the possibility of some of them disappearing and thus causing great damage to future generations should be taken into account [55].

\subsection{Selected Motives for Changing Consumer Behaviour on the Food Market}

Food sustainability involves many interlinked factors, including nutrition, environmental impact, cultural preferences, security and food systems [56]. Adequate, safe, diversified and nutritious food contributes to a healthy diet; however, there are limitations due to resource scarcity and environmental degradation, as well as unsustainable production, food losses, and unsustainable distribution and consumption patterns, which affect consumers' diets [27]. The theory of consumer behaviour assumes that the consumer is a rational economic factor whose aim is to achieve maximum satisfaction with inexpensive, nutritious and safe food, as well as its attributes (e.g., taste, colour and aroma) [57]. For a food product to be acceptable, consumers should specify the product that suits their preference. Understanding consumer preferences and behaviour is therefore an important aspect in designing sustainable dietary interventions as well as in creating a sustainable food system. Taking into account consumer preferences and consumer behaviour when developing products will have a positive impact on physical and economic access to a variety of products based on leguminous plants that are suitable, culturally acceptable and consumed sustainably [58].

Consumers are taking decisions while bearing sustainability in mind more and more often, as well as being aware of the consequences of their decisions for their own health and the environment. The domain of today's consumers is primarily the awareness of the effects of decisions taken, mainly due to their wide access to information and their active social participation. Moreover, the consumer has an idea of the quality of products and, at the same time, of the price/quality ratio. The contemporary consumer shapes the structure of his/her consumption more responsibly and is able to assert his/her consumer rights [59].

A number of factors influence a consumer's decision-making process on the market. In the literature, they are described as determinants of consumer behaviour. As a rule, many of them occur at the same time and their combination determines a certain aspect of consumer behaviour on the market [60]. The consumption process is shaped by many different economic factors (e.g., increase in consumer income and wealth) and non-economic factors (demographic, cultural, social, psychological, etc.). Consumer decisions are strongly influenced not only by objective but also subjective factors, e.g., habits, way of life [61,62].

Economic factors are among the most important factors in food selection. A consumer's food consumption is determined by the supply of goods on the market, as well as the income at their disposal, the real value of which is determined by food prices. The place of residence also influences purchasing decisions. It can be associated with the availability of products and the fact that rural regions are generally poorer and urban agglomerations are richer, hence the differences in consumer behaviour in the food market. Inhabitants of rural regions, due to costs and less developed infrastructure, prefer to prepare their own meals, while inhabitants of cities more often benefit from the various offers of food delivery companies and restaurants. In this case, the determining factor is the price the consumer 
pays for primary and secondary products [63]. V. Inglis et al. [64] underline the importance of food prices in consumers' purchase decisions. Research has shown that prices are a major barrier limiting access to healthy food for people with low incomes. Food expenditure is often a flexible part of the household's budget, which means that consumers rarely plan it in advance. A low income restricts access to a sufficient amount of high-quality food, as it makes it impossible to make a purchase for health reasons [65-67].

Growing health awareness can also be an important factor in consumers' purchasing decisions $[68,69]$. A change in dietary behaviour and diet to more healthy and environmentally friendly choices is also linked to the need to ensure nutrition for present and future generations in the face of the overexploitation of natural resources and the dynamics of demographic change on a global scale. According to the Food and Agriculture Organisation of the United Nations [27], a balanced diet protects and respects biodiversity and ecosystems, is culturally acceptable, economically accessible to all sections of the population and nutritionally appropriate, as well as safe and healthy, optimising natural and human resources. Several sets of recommendations have been developed to identify the key attitudes that are conducive towards achieving sustainable consumption model. One of the models, referring to the dietary recommendations, was the one developed by scientists from the Barilla Center for Food \& Nutrition (BCFN), named the Double Pyramid Model (the food pyramid and the environmental pyramid) (Figure 1).

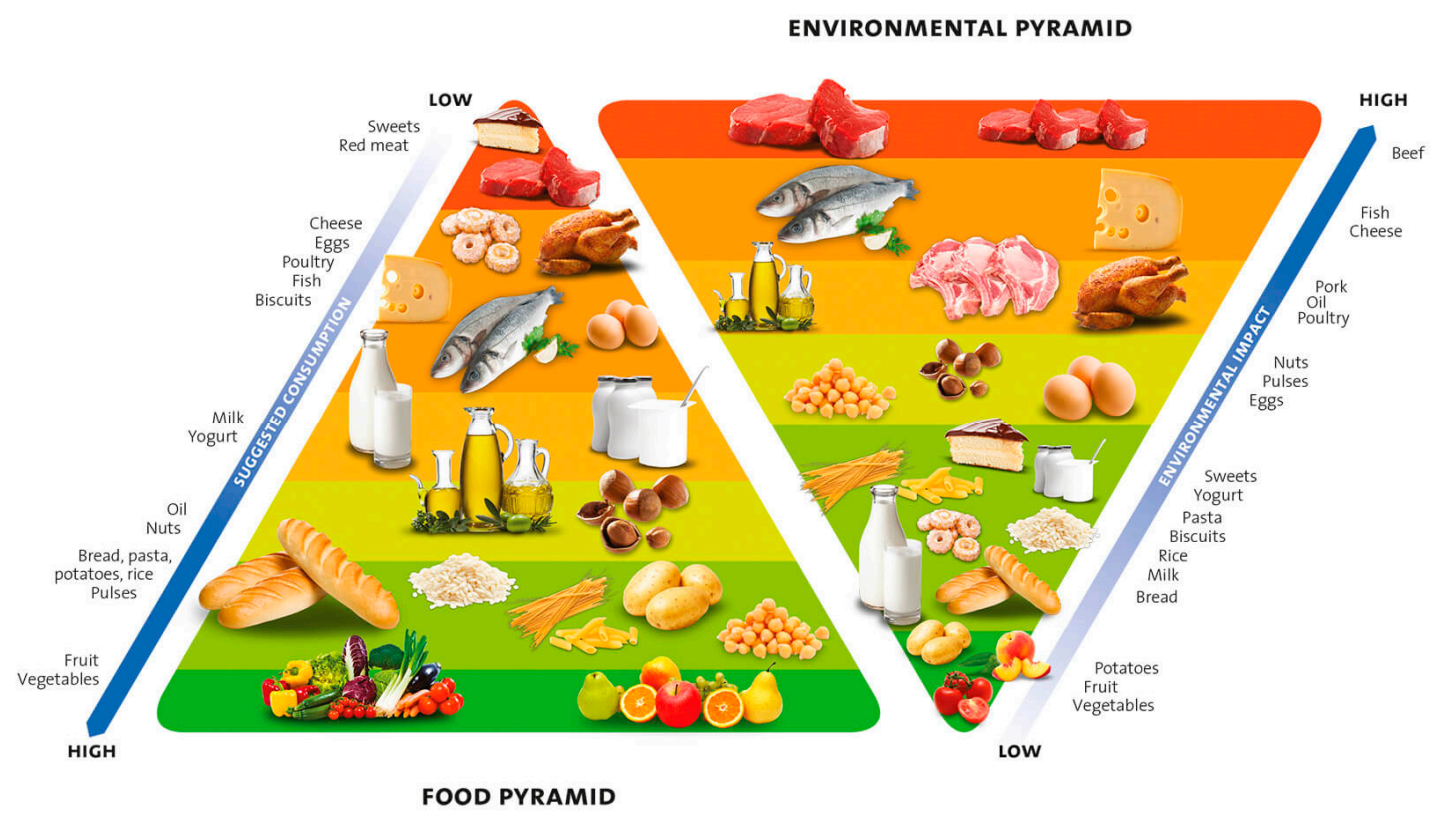

Figure 1. The double food and environmental pyramid model. Source: https://www.barillacfn.com/en/ dissemination/double_pyramid/.

The food pyramid was created based on the nutritional properties of food. The environmental pyramid, however, reflects the environmental impact of food. As a result, an inverted food pyramid was created, i.e., at the top of the pyramid, there are products with the greatest impact on the environment, and at the bottom those with the least impact. Placing two pyramids next to each other illustrates that food with the highest recommended intake (e.g., fruits, vegetables or legumes) has the smallest impact on the environment. On the other hand, products whose consumption should be limited, including red meat, have the biggest impact on the environment [70].

In 2015, the World Wide Fund for Nature developed, in relation to an environmentally balanced and healthy diet for the modern consumer, the implications of a sustainable consumption model in combination with nutritional recommendations, taking cultural and economic differences into account, entitled "Livewell Plate 2020". The analyses carried out within the Live Well for Life project 
emphasise that the proposed changes may contribute to a reduction in greenhouse gas emissions from the food chain by $25 \%$ by 2020 in relation to 1990, while remaining economically accessible to broad social groups [71-73]. The WWF's (World Wildlife Fund) recommendations for consumption include increasing the consumption of leguminous plants, nuts, seeds and vegetables and reducing the amount of meat and animal products consumed. Several principles which draw attention to key aspects for the implementation of the recommendations of the sustainable consumption model were developed. These principles are as follows: eat more plants; eat diversified foods; do not waste food; reduce the consumption of all types of meat; use protein sources such as leguminous plants or nuts; buy food with reliable quality certificates (e.g., fair-trade); eat less food rich in fat, salt and sugar; eat products such as cakes, sweets, chocolates, chips and crisps occasionally; choose water instead of sweetened drinks [74]. In 2017, the WWF published the Eating for 2 degrees report which presents new and updated sustainable "Livewell Plates". The recommendations focus on the implementation of nutritional requirements for four population groups (adults, elderly people, children, vegans), taking into account the reduction in the negative environmental impact of the diet used [75]. Instructions concerning an increase in the consumption of legumes are justified not only from a nutritional perspective, but also by socio-economic and environmental reasons [76,77].

\section{Material and Methods}

\subsection{Sample and Study Design}

In the study, a diagnostic survey with an authorial questionnaire was used (the questionnaire was prepared in Polish, due to the country in which the study was conducted). The questionnaire contained three sections containing data on the demographic statistics of the participants of the study, their knowledge of legume products, their identification and the tendency towards their consumption (the most frequently purchased products). The study was carried out from December 2019 to February 2020. The questionnaire contained 18 research questions and additional questions defining the sociodemographic characteristics of the respondents. The questions concerned the consumer's knowledge about legumes, their health benefits, purchasing preferences, reasons for paying attention to legumes, the frequency of consumption of meals from these products and other aspects. In this paper, a part of the questionnaire concerns the purchasing preferences of the respondents and their awareness of the concept of sustainable development.

The proprietary questionnaire primarily employed five-point Likert scales containing the following response categories: "I strongly disagree", "I disagree", "Neither agree nor disagree", "I agree”, and "I strongly agree". In additional, the five-point rank scale was used to measure attitudes, following the use of a procedure of construction and validation. The consumption frequency of the products was measured on a scale from 0 to 5, where 0 means "I don't eat it", 1 means "I eat it less than once a month", 2 means "I eat it once or twice a month", 3 means "I eat it once or twice a week", 4 means "I eat it three or four times a week", 5 means "I eat it every day". The Cronbach's alpha test was used to assess the reliability of the measurement scales. It adopted a value of 0.85 , which refers to the correct reliability of the scales. In determining the study sample size, the confidence level was set at 0.95 , the estimated fraction size at 0.50 and the maximum error at $0.03[78,79]$. The study sample was established from the entire adult population of Poland, which amounted to 31,532,048 people [80]. The study sample size was established with 1067 respondents (Table 1.) (1618 questionnaires were sent to randomly selected respondents—only 1067 were completed correctly; the rest of the questionnaires were rejected), who were selected by taking into account the following: their place of residence (rural areas, cities of up to 30,000 inhabitants and more than 30,000), age (up to 25, 26 to 40,41 to 55 and 56 and more), and gender from 6 particular Polish regions (Figure 2). For the purposes of this study, the definition of rural areas was adopted in accordance with the Central Statistical Office, which characterises rural areas on the basis of the territorial division of the country according to the National Official Register of Territorial Division (TERRIF). Rural areas are areas outside the 
administrative borders of cities; they include communes (name of the Polish territorial unit), and the rural areas of urban-rural communes [80]. The established number of respondents was a representative sample of these regions: Central-220, South-222, East-188, South-West-109, North-West-164 and North-164 respondents. Women constituted $52.3 \%$, while men $47.7 \%$ of the respondents in the sample. The study was conducted using the Computer-Assisted Web Interview (CAWI) method, applying all the criteria outlined. A database purchased for the purposes of carrying out previous projects RKU/DS/2 within the Department of Agritourism and Rural Development of the University of Life Sciences in Lublin was used.

Table 1. Demographic description of the sample $(n=1067)$.

\begin{tabular}{cccc}
\hline Variable & Category & Frequency & Percentage (\%) \\
\hline \multirow{2}{*}{ Gender } & Male & 509 & 47.70 \\
& Female & 558 & 52.30 \\
\hline \multirow{2}{*}{ Age } & $<25$ & 312 & 29.24 \\
& $26-40$ & 238 & 22.27 \\
& $41-55$ & 299 & 28.02 \\
Place of residence & $>56$ & 218 & 20.47 \\
& Cities of up to 30,000 inhabitants & 420 & 39.40 \\
& Cities more than 30,000 inhabitants (cities) & 452 & 18.00 \\
& (urban-rural communes) & 42.60 \\
\hline \multirow{2}{*}{ Level of } & Primary & 341 & 32.00 \\
& Secondary & 393 & 36.80 \\
& University & 333 & 31.20 \\
\hline
\end{tabular}

Source: Author's own analysis based on study material.
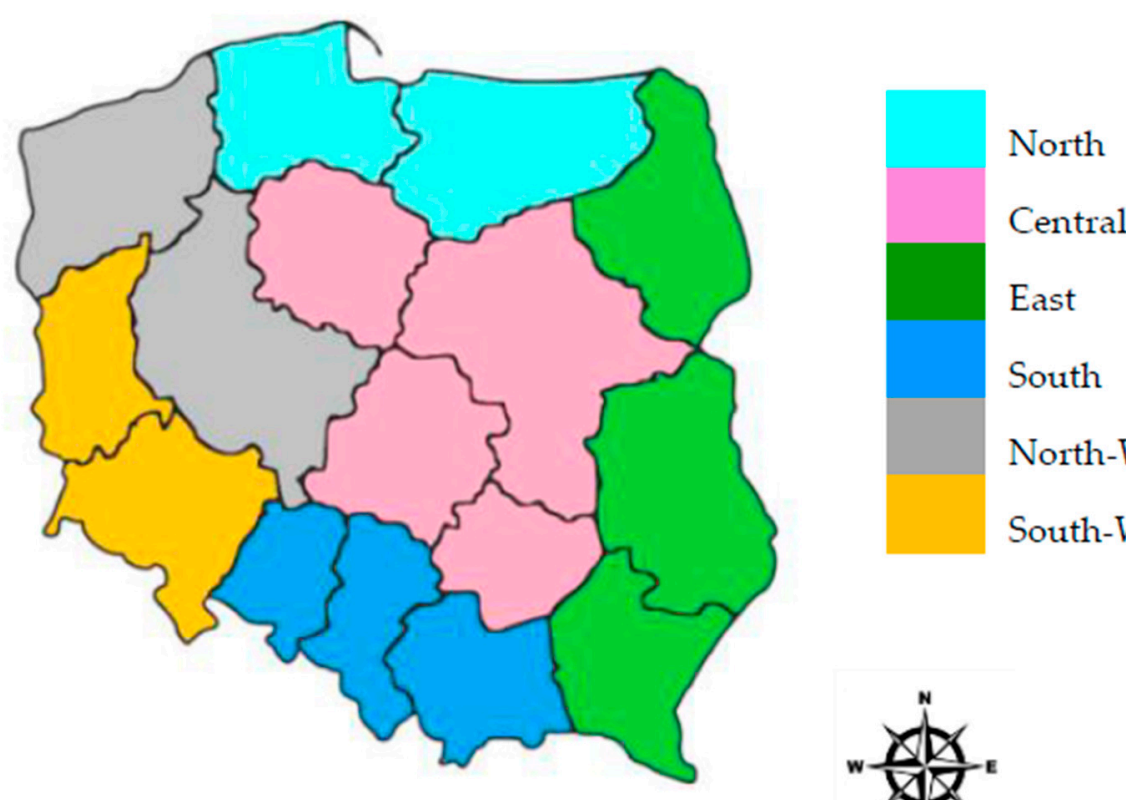

Central

East

South

North-West

South-West

Figure 2. Division of Poland into regions. Source: Author's own project.

\subsection{Statistical Analyses}

The programme Statistica 13.1 PL (StatSoft Inc., Tulsa, OK, USA) was used in the statistical analyses. In order to decide which variables distinguished three naturally arising groups, a discriminant function analysis was applied, as it allowed us to examine the differences between groups of objects based on a set of selected independent variables (predictors). Furthermore, this analysis is used in correlation 
studies, i.e., when causal links between variables are not well recognised. A classification function in the form of a coefficient calculation defined for every group of variables was used in the study. Linear regression statistics were also used to find the equation that best predicts the dependent variable as a linear function of independent variables—-this was the reason for using multiple linear regression.

$$
\mathrm{Y}=\mathrm{b}_{0}+\beta_{1 \times 1}+\beta_{2 \times 2}+\ldots+\beta_{\mathrm{k} \times \mathrm{k}}+\varepsilon
$$

$\mathrm{b}_{0}$-constant;

$\beta_{\mathrm{i}}$-model parameter (of regression factors) describing the effect of $i$-th variable;

$\beta_{1}, \cdots, \beta_{\mathrm{k}}$-partial regression factors;

$\mathrm{x}_{1}, \ldots, \mathrm{x}_{\mathrm{k}}$-variable examined;

$\varepsilon$-random component (Se).

Before the analyses were undertaken, multidimensional normality was examined, checking each variable for the normality of distribution. It was assumed that the variable variance matrices were homogeneous in the groups. The standard deviation was not taken into account due to the large number of respondents in particular groups. The differences in the means with a probability of randomness lower than $p<0.05$ were specified as statistically significant.

The following hypotheses were made:

Hypothesis 1 (H1): The place of residence of the consumer affects their level of knowledge about legumes and the availability of products for consumption.

Hypothesis 2 (H2): The existing differences in the motives for buying legume products also depend on the place of residence of the consumer.

Hypothesis 3 (H3): There are statistical differences in the consumer's behaviour when choosing the place/channel of purchase, depending on the consumer's place of residence.

Hypothesis 4 (H4): The awareness of health and environmental benefits affects the purchase of legume products.

\section{Results}

According to the results obtained in the study, legume products have found their market niche in Poland, and their popularity is increasing gradually. The respondents were asked to select at least three of the legume products most frequently purchased/used by them. Table 2 contains a comparison of the legume products' popularity, classified by the place of residence of the consumers surveyed. All the selected products obtained high means, which is due to the general availability of these products not only in shops, bazaars and local greengrocers', but also in the cultivation of these plants (in the case of rural residents or allotment holders), as they are not particularly demanding to grow and are quite popular. For rural residents, in their ranking of legume products, the first four places were peas, beans, lentils and soybeans; for residents of cities of up to 30,000 inhabitants, it was, respectively, beans, soybeans, chickpeas and broad beans; for residents of cities of more than 30,000 inhabitants, the ranking of the first four places was quite reversed: lentils, peas, soybeans and beans. It should be noted that, among the inhabitants of rural areas and cities of more than 30,000 inhabitants, the set of legume products was the same. The difference was in the ranking positions. The reason may be that all legumes listed in Table 2 are cultivated in Poland and are easily accessible to residents of rural areas, as well as to residents of larger cities, where there are more shops with a wide range of canned, dried and frozen legume products. Despite good market recognition by the consumer and the tendency to buy and use these products, there are significant differences between consumers according to their place of residence for all products proposed in the evaluation. 
Table 2. Comparison of legume products desired by consumers in terms of the consumer's place of residence. The consumer had at least three products to indicate.

\begin{tabular}{ccccccccc}
\hline \multirow{2}{*}{$\begin{array}{c}\text { Variable/Legume } \\
\text { Product }\end{array}$} & $\begin{array}{c}\text { Rural } \\
\text { Area }\end{array}$ & $\begin{array}{c}\text { City of up } \\
\text { to 30,000 } \\
\text { Inhabitants }\end{array}$ & $\begin{array}{c}\text { City of more } \\
\text { than 30,000 } \\
\text { Inhabitants }\end{array}$ & $\begin{array}{c}\text { Rural } \\
\text { Area }\end{array}$ & $\begin{array}{c}\text { City of up } \\
\text { to 30,000 } \\
\text { Inhabitants }\end{array}$ & $\begin{array}{c}\text { City of more } \\
\text { than 30,000 } \\
\text { Inhabitants }\end{array}$ & $t$-Test & $p$-Value \\
\hline Peas & 1 & 6 & 2 & 3.868 & 3.065 & 3.904 & 25.174 & $<0.000^{*}$ \\
Beans & 2 & 1 & 4 & 3.795 & 3.786 & 3.536 & 12.551 & $<0.000^{*}$ \\
Lentils & 3 & 5 & 1 & 3.366 & 3.310 & 4.035 & 29.770 & $<0.000^{*}$ \\
$\begin{array}{c}\text { Soybean } \\
\text { Chickpea (Cicer }\end{array}$ & 4 & 2 & 3 & 3.360 & 3.577 & 3.632 & 18.380 & $<0.000^{*}$ \\
arietinum L.) & 5 & 3 & 6 & 3.357 & 3.449 & 3.051 & 22.476 & $<0.000^{*}$ \\
Coronilla L. & 6 & 7 & 7 & 3.250 & 2.815 & 3.014 & 23.397 & $<0.000^{*}$ \\
Broad beans & 7 & 4 & 5 & 3.120 & 3.442 & 3.238 & 17.413 & $<0.000^{*}$ \\
\hline
\end{tabular}

Note: * Level of significant difference at $p<0.050$. Source: Author's own analysis based on study material.

Taking into account the place of residence of the respondents, information on the motives that influence their decisions to purchase legume products was obtained. The proposed model of discriminant analysis included seven variables. Table 3 presents, in detail, the statistically significant discriminant differences in the studied groups in terms of motives influencing the purchase decisions. The significance of the studied variables in the hierarchy from the highest to the lowest value of analysis was as follows: "legumes have a high protein and/or fibre content" $(\mathrm{F}=24.518 ; p=0.001)$, "affordability of the products" ( $\mathrm{F}=18.658 ; p=0.001)$, "flavour" (8.356; $p=0.011)$; "ethical reasons for choosing legumes" ( $\mathrm{F}=7.928 ; p=0.001)$, "ease of meal preparation" ( $\mathrm{F}=7.445 ; p=0.001)$, "the products are an alternative to meat products" ( $\mathrm{F}=4.982 ; p=0.001)$, "a large selection of products, e.g., beans, peas, etc." $(\mathrm{F}=2.445 ; p=0.002)$. The classification function reached its highest value for the variable "Legume products are affordable". This variable is most important for respondents that live in cities of up to 30,000 inhabitants (1.725) and in rural areas (1.658); the reason might be that the inhabitants of small cities and rural areas earn less than the inhabitants of large agglomerations. The flavour of legume products and the dishes that can be prepared from them are of great importance for residents of smaller cities (1.698). The residents of rural areas (1.144) and larger cities (1.256) were of a similar opinion. The result is probably influenced by the education of the society in terms of the beneficial effects of consuming legume products-numerous television programmes speak of the health effects of these vegetables in the diet, including culinary programmes. Furthermore, the cultivation of legumes at allotments is becoming popular again. Being an alternative to meat products is an important asset for residents of larger cities (1.618) and rural areas (1.458), more so than for residents of small cities (0.928). The reason for this might be that legumes are cultivated in home gardens in rural areas and are easily accessible in the majority of shops in large cities. Moreover, the popularity of various protein, vegetarian and vegan diets has gained great significance recently. Among the studied motives, "ease of meal preparation" had the smallest importance for the respondents coming from rural areas (0.024); also, for the inhabitants of large cities (0.401), this variable had the lowest value. For the inhabitants of cities of up to 30,000 , the least significant variable had the possibility of a large selection (0.347).

Table 3. Consumer decision-making variables taken into account when shopping.

\begin{tabular}{|c|c|c|c|c|c|c|}
\hline \multirow{3}{*}{ Decision Variable } & \multirow{2}{*}{\multicolumn{3}{|c|}{$\begin{array}{c}\text { Model of Discriminant Analysis } \\
\text { Wilks' Lambda: } 0.437 \\
\text { F }(10.212)=6.945 p<0.001 *\end{array}$}} & \multicolumn{3}{|c|}{ Classification Functions } \\
\hline & & & & \multicolumn{3}{|c|}{ Place of Residence } \\
\hline & $\begin{array}{l}\text { Wilks' } \\
\text { Lambda }\end{array}$ & F Value & $p$ Level & $\begin{array}{c}\text { Rural Area } \\
p=0.560\end{array}$ & $\begin{array}{l}\text { City of up } \\
\text { to } 30,000 \\
\text { Inhabitants } \\
p=0.430\end{array}$ & $\begin{array}{c}\text { City of more } \\
\text { than } 30,000 \\
\text { Inhabitants } \\
p=0.580\end{array}$ \\
\hline Legumes have a high protein and/or fibre content & 0.472 & 24.518 & 0.001 * & 1.618 & 1.443 & 0.658 \\
\hline Ethical reasons for choosing legumes & 0.466 & 7.928 & 0.001 * & 0.189 & 0.408 & 0.665 \\
\hline An alternative for meat products & 0.513 & 4.982 & 0.001 * & 1.458 & 0.928 & 1.618 \\
\hline
\end{tabular}


Table 3. Cont.

\begin{tabular}{|c|c|c|c|c|c|c|}
\hline \multirow{3}{*}{ Decision Variable } & \multirow{2}{*}{\multicolumn{3}{|c|}{$\begin{array}{c}\text { Model of Discriminant Analysis } \\
\text { Wilks' Lambda: } 0.437 \\
\text { F }(10.212)=6.945 p<0.001 *\end{array}$}} & \multicolumn{3}{|c|}{ Classification Functions } \\
\hline & & & & \multicolumn{3}{|c|}{ Place of Residence } \\
\hline & $\begin{array}{c}\text { Wilks' } \\
\text { Lambda }\end{array}$ & F Value & $p$ Level & $\begin{array}{c}\text { Rural Area } \\
p=0.560\end{array}$ & $\begin{array}{l}\text { City of up } \\
\text { to } 30,000 \\
\text { Inhabitants } \\
p=0.430\end{array}$ & $\begin{array}{l}\text { City of more } \\
\text { than } 30,000 \\
\text { Inhabitants } \\
p=0.580\end{array}$ \\
\hline Affordable & 0.509 & 18.658 & $0.001 *$ & 1.658 & 1.725 & 1.103 \\
\hline Easy to prepare & 0.498 & 7.445 & $0.001 *$ & 0.024 & 0.523 & 0.401 \\
\hline They are tasty & 0.459 & 8.356 & 0.011 * & 1.144 & 1.698 & 1.256 \\
\hline $\begin{array}{c}\text { There is a large selection (e.g., beans, peas, } \\
\text { broad beans, lentils) }\end{array}$ & 0.484 & 2.445 & $0.002 *$ & 0.123 & 0.347 & 0.623 \\
\hline Constant & & & & 10.761 & 13.613 & 12.971 \\
\hline
\end{tabular}

Note: The tested hypothesis in the model of purchase motives for legumes concerns whether the decision variable makes a significant contribution to the model. * Level of significant difference at $p<0.050$. Source: Author's own analysis based on study material.

The respondents were asked to comment on the places where they purchase legume products (Table 4). Statistically significant variables that determined the places of purchase in a discriminant analysis, from the highest to the lowest, were: "hypermarkets and supermarkets" $(\mathrm{F}=24.285$; $p=0.001)$, "local stores" ( $\mathrm{F}=6.177 ; p=0.003)$, “local bazaars and marketplaces" $(\mathrm{F}=5.460 ; p=0.019)$, "specialised world cuisine stores" ( $\mathrm{F}=5.249 ; p=0.001)$, and "mail order/internet" ( $\mathrm{F}=4.924 ; p=0.001)$. The classification function reached its highest values for the variable defining hypermarkets and supermarkets as the place of purchase of legume products. The declarations made among the inhabitants of large cities amounted to 3.051, compared to 3.234 cases among the inhabitants of small cities and 2.981 respondents coming from rural areas. This shopping channel was the most popular among the consumers of all the groups studied. The reason for this may be a good shop supply of the articles sought by the consumer and a wide range of products: fresh, frozen, canned and dried articles. Moreover, the prices in the hypermarkets and supermarkets are statistically more affordable for the average consumer than the prices in specialised shops. Mail order/online shopping was another very popular channel among consumers. It was of greater importance for the respondents from large cities (2.048) than for the inhabitants of small cities (1.241) and rural areas (1.547). The advantage of this channel is the possibility of saving time, which is important for the inhabitants of urban agglomerations, and a wide range and availability of products, which in turn may be the reason for this channel's preference among the inhabitants of rural areas. The smallest importance for the inhabitants of rural areas had the possibility to purchase legumes from a local bazaar or marketplace (0.012). Specialised world cuisine stores, as a shopping channel, were of a considerable interest among the inhabitants of large cities (1.642), but analysing the results of all shopping channels for the group of respondents from cities of more than 30,000 inhabitants it was of a comparable importance to the "local bazaars and marketplaces" shopping channel (1.675).

Table 4. Place of purchase of legume products according to the place of residence of the respondents.

\begin{tabular}{|c|c|c|c|c|c|c|}
\hline \multirow{3}{*}{ Place of Purchase } & \multirow{2}{*}{\multicolumn{3}{|c|}{$\begin{array}{c}\text { Model of Discriminant Analysis } \\
\text { Wilks' Lambda: } 0.528 \\
\text { F }(10.212)=6.945 p<0.001 *\end{array}$}} & \multicolumn{3}{|c|}{ Classification Functions } \\
\hline & & & & \multicolumn{3}{|c|}{ Place of Residence } \\
\hline & $\begin{array}{c}\text { Wilks' } \\
\text { Lambda }\end{array}$ & F Value & P Level & $\begin{array}{c}\text { Rural Area } \\
p=0.560\end{array}$ & $\begin{array}{c}\text { City of up } \\
\text { to } 30,000 \\
\text { Inhabitants } \\
p=0.430\end{array}$ & $\begin{array}{c}\text { City of more } \\
\text { than } 30,000 \\
\text { Inhabitants } \\
p=0.580\end{array}$ \\
\hline In supermarkets and hypermarkets & 0.410 & 24.285 & $0.001 *$ & 2.981 & 3.234 & 3.051 \\
\hline At local stores & 0.347 & 6.177 & 0.003 * & 0.988 & 0.911 & 1.799 \\
\hline At local bazaars and marketplaces & 0.521 & 5.460 & $0.019 *$ & 0.012 & 0.758 & 1.675 \\
\hline
\end{tabular}


Table 4. Cont.

\begin{tabular}{|c|c|c|c|c|c|c|}
\hline \multirow{3}{*}{ Place of Purchase } & \multirow{2}{*}{\multicolumn{3}{|c|}{$\begin{array}{c}\text { Model of Discriminant Analysis } \\
\text { Wilks' Lambda: } 0.528 \\
\text { F }(10.212)=6.945 p<0.001 *\end{array}$}} & \multicolumn{3}{|c|}{ Classification Functions } \\
\hline & & & & \multicolumn{3}{|c|}{ Place of Residence } \\
\hline & $\begin{array}{l}\text { Wilks' } \\
\text { Lambda }\end{array}$ & F Value & P Level & $\begin{array}{c}\text { Rural Area } \\
p=0.560\end{array}$ & $\begin{array}{l}\text { City of up } \\
\text { to } 30,000 \\
\text { Inhabitants } \\
p=0.430\end{array}$ & $\begin{array}{c}\text { City of more } \\
\text { than } 30,000 \\
\text { Inhabitants } \\
p=0.580\end{array}$ \\
\hline Specialised world cuisine stores & 0.335 & 5.249 & $0.001 *$ & 0.483 & 1.205 & 1.642 \\
\hline Online/mail order sales & 0.274 & 4.924 & $0.001 *$ & 1.547 & 1.241 & 2.048 \\
\hline \multicolumn{4}{|c|}{ Constant } & 7.761 & 9.591 & 8.846 \\
\hline
\end{tabular}

Note: The tested hypothesis in the model defining the preferred places of purchase of leguminous products concerns whether the selected place makes a significant contribution to the model. ${ }^{*}$ Level of significant difference at $p<0.050$. Source: Author's own analysis based on study material.

In order to determine whether the perception of legume products affects sustainable development, the respondents were asked to assess the statement: "The consumption of legume products contributes to the sustainable development" (response suggestions were encoded in a five-level scale), which was used as a dependent variable in the regression analysis (Table 5). The data were analysed using a linear regression procedure and the set of factors obtained in the factor analysis for each group of samples was used as the predictors. By performing linear regressions, the authors wanted to find and explain the relationship between independent variables and dependent variables.

Table 5. Linear regression analysis for the variables describing the relationship between the pro-environment awareness and the tendency to purchase legume products.

\begin{tabular}{cccc}
\hline Factors & Estimate $(\beta)$ & Standard Error & $p$-Value \\
\hline Caring for the environment and animal welfare (A) & 0.045 & 0.269 & 0.012 \\
No harmful substances used in its production (B) & 0.439 & 0.022 & $<0.001$ \\
Low level of processing, short shelf life (C) & 0.130 & 0.159 & $<0.001$ \\
\hline F-statistic of the model & & $\mathrm{F}(1.428)=0.342$ & \\
Constant & & 2.267 & \\
Se & & 56.118 & \\
Coefficient of determination $\left(R^{2}\right)$ & & $56.3 \%$ & \\
\hline
\end{tabular}

Note: Level of significant difference at $p<0.050$. Source: Author's own analysis based on study material.

The coefficient of determination $R^{2}$ is 0.563 , which means that the model explains the relations between the variables as $56.3 \%$. Among the suggested variables determining consumer awareness, the model includes three variables, as presented in the table below.

The combination of variables presented in the Table 5 shows the anticipated contribution of legume products in relation to sustainable development, with all three variables significantly affecting the anticipated consumer model. The $\beta$ values are as follows: the largest coefficient indicating which independent variable has the greatest influence on the dependent variable is "No harmful substances used in its production" (B), then "Low level of processing, short shelf life" (C) and, finally, "Caring for the environment and animal welfare" (A). The regression equation looks like this:

$$
\mathrm{Y}=2.267+0.045 \mathrm{~A}+0.439 \mathrm{~B}+0.130 \mathrm{C} \pm 1.118
$$

\section{Discussion}

\subsection{General Knowledge}

The food sector is facing an increasingly competitive and globalised market, and consumers are more demanding and more concerned about the quality and health benefits of products [81]. 
Consumption is among the drivers of food production, and exerts its influence on sustainability [82]. This study was carried out in order to verify and establish consumers' tendencies to consume legume products, which are becoming increasingly popular thanks to their nutritional value. Current changes in the economy are causing changes in consumption and consumer behaviour. Today's consumer is aware of the health benefits of the food on the market $[83,84]$. Knowledge about the health benefits of products is disseminated by various media. Such tools as the internet allow us to gain knowledge about food products, but also enable their purchase [85], a method which is mostly used by consumers of large cities who want to have a wider choice of products (this was confirmed in the presented studies). For consumers in Europe, the health effects are perceived to be a big driver in the demand for legume-based products [86]. A healthy lifestyle, which has been gaining popularity recently, has led to an increasing demand for products that can serve as, for example, meat replacements and contain a large nutritional value. Lea et al. [87] in their research pointed to a change in food product consumption trends-the appreciation of products of plant origin. This is due to the large selection of legumes, as consumers who took part in the survey highly rated the wide selection and variety. It should be mentioned that the gluten-free segment in the food market has attracted a lot of interest from food innovators. This is because legume-based flours can add functionality to gluten-free baking. More and more consumers in the EU and the US are looking for gluten-free products, and this strong market trend will stimulate the demand for legume-based flours produced, among others, from fava beans, chickpeas or lentils [86].

In a study carried out by Figueira et al. [88], Australian researchers, like the authors of this article, pointed to positive consumer attitudes towards legume products. They proved, in a representative sample, that, according to Australian consumers, legume products have a beneficial effect on health, reducing the risk of heart diseases [89]. The health aspect can be an impulse to change consumer behaviour [90]. As a result, developed countries such as the USA or Australia introduced educational programmes aimed not only at diet preparation or culinary skills development, but also at school education and well-thought-out shopping [91]. According to the guidelines of the U.S. Department of Health [92], participation in education, introducing pro-healthy consumption patterns and making consumers aware of the demands of sustainable development can increase legume consumption, resulting not only in a beneficial effect on the diet, but also on the environment.

Malczyk and Kosmaty [93], in their research, presented results on the recognition and consumption of legume products among young consumers of small towns and rural populations that are in parallel with those presented in this article. Beans and peas, as well as soybeans, are popular. Young people are also aware of the health benefits that meals prepared from legumes offer.

Sustainable consumption concerns the effect of nutrition on environmental results, such as the journey from the field to the plate, as well as removing waste [94]. Sustainable food development is essential to ensure a safe and healthy food supply for the population over time and for future generations. Global food production is responsible for over $70 \%$ of fresh water consumption, $80 \%$ of deforestation and up to $30 \%$ of greenhouse gas emissions (GHG). Energy costs, population growth, climate change and changes in nutrition put pressure on land use, soil quality and sustainable water sources in the future [95]. Legumes such as lentils and peas have a lower carbon footprint because they are nitrogen-fixing plants that require very little nitrogen fertiliser [96]. Polish consumers who took part in the study also stressed the values of sustainable development. The equation presenting the contribution of legume products shows that sustainable development aspects affect the consumer model.

Palmer et al. [97], in a study carried out among consumers from the USA (Iowa), emphasised the importance of low-price legume products. The same results were obtained in the present paper, as inhabitants of poorer rural regions prefer to buy products in chain hypermarkets, where prices are lower. The sustainability of diets does not only include nutritional and environmental concerns, but also economic and socio-cultural dimensions [98]. Polish consumers also noticed this aspect and emphasised its importance. The results obtained by the researchers confirm the thesis of the American scientists from Iowa, in that a low price is a condition for choosing these products in rural regions. 
Majili et al. [82], in their research, also emphasised the popularity of legume products in poor rural regions. Poland is a country of contrasts. According to Eurostat [99], the Warsaw region is among the 20 richest regions in Europe, while three rural regions in Poland are among the poorest. The contrast shows that, among the inhabitants of towns, leguminous plants are also popular. The condition for their choice, in turn, is not a low price, but the current trend of various cuisines in the world (for example, Hiddish, Mexican or Mediterranean), where one of the main ingredients are leguminous, so specialist stores or mail order sales are very popular in large cities. Similar results are presented by Australians, showing the dependence of purchasing legume products on culinary preferences [88].

Legume products sold in shops in Poland are usually manufactured from local resources [12]. In a study carried out on Polish consumers, Wojciechowska-Solis [100] pointed out that the Polish consumer is an ethnocentrist; in knowing about the local origin of products or about their production from local resources, they prefer domestic products. The nature of Polish consumers' ethnocentrism is primarily concerned with economic health, for example, product ethnocentrism and the responsibility for jobs [101]. Consumption ethnocentrism manifests itself because products without any intermediaries in the supply chain are cheaper [102], which is directly reflected in the shopping carts of Polish consumers.

According to Kostakis [103], consumers living in rural areas can produce their own products and consumers in urban areas have more food consumption choices, leading them to have higher food expenditures, due to more sales channels, such as marketplaces, various community stores, specialist stores and others. The consumers who took part in the study, similar to Greek consumers in rural areas, benefit from their land, while city dwellers benefit from a variety of store offers.

In this study, knowledge of the nutritional benefits of leguminous plants was considered a positive motive for increasing the consumption of these foods. However, in studies conducted among French consumers, this was not a sufficient reason to change their shopping habits [104]. In a study conducted by the Jallinoja et al. team [105], environmental awareness was not convincing enough to induce consumers to eat more legumes. In turn, natural concerns, health and weight control motives were considered important for those whose diet included beans and other legume products [106]. In our study, consumers presented pro-ecological attitudes, declaring, "Caring for the environment and animal welfare", "No harmful substances used in its production" and "Low level of processing, short shelf life". Similarly, a survey conducted among Polish residents of large cities by the team of Rejman et al. [107] showed that care for the environment plays the greatest role among "adopting" for the cluster related to a balanced diet.

The research conducted by the authors can be considered as among the first of its kind in Eastern Europe. It concerns the combination of consumers' purchasing intentions and their impact on sustainability. It is very important to determine whether the consumer understands what sustainability is and what impact it has on quality of life. It is important to provide the consumer with this knowledge. Making them aware that even the choice of products at a stall, in a supermarket, via the internet, or directly from a farmer has an impact not only on their health, the economic situation in their direct surroundings, but also globally on the environment. In the current study, the authors focused on consumer behaviour in the market of leguminous products because they believe that their consumption combines health and environmental aspects. According to scientists, these motives are very important for society when shopping these days $[108,109]$. Despite the fact that the majority of study participants in rural areas and cities believed that legumes were a good alternative to meat, Finnish researchers say that it is beneficial to make a change in which eating meat and vegetarianism are not viewed as opposites, but as a continuum that would allow consumers to perhaps develop a more relaxed attitude towards eating plant-based proteins, which could eventually become a routine and embodied practice in everyday life, contributing to sustainable consumption [110]. It is likely that habits that are first adopted by some social groups may later be adopted by other groups as well, and this can be achieved, e.g., by systematically keeping beans, tofu, and other soy-based foods in menus such as school canteens, bistros and other places. 
Further research should follow trends that combine health and sustainability aspects in order to identify the needs of future consumers. However, we also must not forget about the price aspect of the goods under investigation.

\subsection{Limitations}

Although this study was conducted on a sample representative of the country, it had some limitations. The main limitation of the study was that not all factors were taken into account. One of the reasons for this was that only some areas were covered by the questionnaire. When conducting future research, one should take into account all aspects (determinants) of consumption and pay particular attention to the importance of labels informing the consumer about the origins of food (e.g., whether the manufacturer applies sustainable development principles, etc.). It is widely known that certification means additional costs, but a recognisable label provides resulted from the choice of a differentiation variable, i.e., the consumer's place of residence consumers with necessary information about the origins of products. Restrictions may have also resulted from the choice of a differentiation variable, i.e., the consumer's place of residence.

\section{Conclusions}

According to many researchers, legume food products in consumers' shopping carts contribute not only to improving population health, but also to improving environmental conditions and supporting the economy.

The dissemination of knowledge about sustainable development is necessary to allow consumers to make more sustainable food choices and increase the effectiveness of food policy instruments. Despite the good prognosis, it is important to continue to educate society about sustainable development issues, namely our contribution as consumers. The products we buy have a direct effect on $\mathrm{CO}_{2}$ emissions and other natural resources. An example of sustainable consumption can be found in legume products. Their cultivation benefits not only the environment, but also consumers in terms of food benefits. Consumers have shown a good knowledge about legumes and the relationship between their cultivation and environmental improvements. This study showed the availability of legume products depending on consumers' place of residence. There are different sales channels for these products, but there are no clear obstacles to purchasing the desired goods. Shops specialising in different world cuisines, offering legume products from different countries, usually sell online in addition to traditional channels. Large-area shops such as hypermarkets and supermarkets are built in small cities, where they get across, with their offers, that they are trying to diversify.

Food sector companies could use the results of this study to prepare a legume product offer and a distribution channel depending on the place of residence of the target consumer.

Author Contributions: Conceptualisation, J.W.-S. and M.Ś.-K.; methodology, J.W.-S.; software, J.W.-S.; validation D.V.; formal analysis, J.W.-S. and M.Ś.K.; investigation, J.W.-S. and M.S.-K.; resources, J.W.-S and M.Ś.-K.; data curation, J.W.-S. and M.Ś.-K.; writing—original draft preparation, J.W.-S. and M.Ś.-K.; writing-review and editing, J.W.-S. and M.Ś.-K; visualisation, J.W.-S. and M.Ś.-K.; supervision, J.W.-S. and M.Ś.-K.; project administration, J.W.-S. and M.Ś.-K.; funding acquisition, M.Ś.-K. All authors have read and agreed to the published version of the manuscript.

Funding: This paper was funded by the Faculty of Economics and Social Sciences, Poznan University of Life Science.

Acknowledgments: This study was funded by the project Consumer behaviour relevant to the quality of life of the rural population-University of Life Sciences in Lublin.

Conflicts of Interest: The authors declare no conflict of interest. 


\section{References}

1. World Population Prospects. The 2012 Revision. Highlights and Advance Tables. Available online: http: //esa.un.org/wpp (accessed on 10 May 2020).

2. Natural Superfoods: Will Pulses Lead the Next Wave of Healthy Eating? Available online: http://www.fao. org/pulses-2016/blog/will-pulses-lead-the-next-wave-of-healthy-eating/en/ (accessed on 1 July 2020).

3. Szczebyło, A.; Halicka, E.; Łuczyńska, K. Spożycie nasion roślin strączkowych w Polsce jako element modelu zrównoważonej konsumpcji żywności (Consumption of pulses in Poland as an element of a sustainable food consumption model). Pragmata Oikonomias 2018, 12, 35-45. [CrossRef]

4. Szczebyło, A.; Rejman, K.; Halicka, E.; Laskowski, W. Towards More Sustainable Diets-Attitudes, Opportunities and Barriers to Fostering Pulse Consumption in Polish Cities. Nutrients 2020, 12, 1589. [CrossRef] [PubMed]

5. Hedenus, F.; Wirsenius, S.; Johansson, D.J.A. The importance of reduced meat and dairy consumption for meeting stringent climate change targets. Clim. Chang. 2014, 124, 79-91. [CrossRef]

6. Tukker, A.; Goldbohm, A.R.; Koning, A.; Verheijden, M.; Kleijn, R.; Wolf, O.; Pérez-Domínguez, I.; Rueda-Cantuche, J.M. Environmental impacts of changes to healthier diets in Europe. Ecol. Econ. 2011, 70, 1776-1788. [CrossRef]

7. McCrory, M.A.; Hamaker, B.R.; Lovejoy, J.C.; Eichelsdoerfer, P.E. Pulse Consumption, Satiety, and Weight Management. Adv. Nutr. Int. Rev. J. 2010, 1, 17-30. [CrossRef]

8. Venter, C.S.; Vorster, H.H.; Ochse, R.; Swart, R. "Eat dry beans, split peas, lentils and soya regularly": A food-based dietary guideline. S. Afr. J. Clin. Nutr. 2013, 26, 36-45.

9. Ceny Rolnicze. W Ciagu Dekady Spożycie Białka Zwierzęcego W Ue Spadnie O 17\%. Available online: https://www.cenyrolnicze.pl/wiadomosci/rynki-rolne/mieso/18044-w-ciagu-dekady-spozycie-bialkazwierzecego-w-ue-spadnie-o-17 (accessed on 10 May 2020).

10. McDermott, J.; Wyatt, A.J. The Role of Pulses in Sustainable and Healthy Food Systems. Ann. N. Y. Acad. Sci. 2017, 1392, 30-42. [CrossRef]

11. Śmiglak-Krajewska, M. Cultivation of legume crops in the context of sustainable agriculture. Rocz. Nauk. Ser. 2018, 20, 255-261. [CrossRef]

12. Jerzak, M.A.; Śmiglak-Krajewska, M. Globalization of the market for vegetable protein feed and its impact on sustainable agricultural development and food security in EU countries illustrated by the example of Poland. Sustainability 2020, 12, 888. [CrossRef]

13. Struik, P.C.; Bonciarelli, F. Resource use at the cropping system level. Eur. J. Agron. 1997, 7, 133-143. [CrossRef]

14. Pociejowska, M.; Natywa, M.; Selwet, M. Praktyczne aspekty biologicznego wiązania azotu atmosferycznego. Wieś Jutra 2013, 1, 55-56.

15. West, T.O.; Post, W.M. Soil organic carbon sequestration rates by till-age and crop rotation: A global data analysis. Soil Sci. Soc. Am. J. 2002, 66, 1930-1946. [CrossRef]

16. Meena, R.S.; Lal, R. Legumes and Sustainable Use of Soils; Springer Nature Singapore Pte Ltd.: Singapore, 2018.

17. Srinivasarao, C.; Venkateswarlu, B.; Lal, R. Long-term effects of soil fertility management on carbon sequestration in a rice-lentil cropping system of the Indo-Gangetic plains. Soil Sci. Soc. Am. J. 2012, 76, 167-178. [CrossRef]

18. Mundt, C.C. Use of multiline cultivars and cultivar mixtures for disease management. Annu. Rev. Phytopathol. 2002, 40, 381-410. [CrossRef] [PubMed]

19. Polskie, B. Rośliny Straczkowe i Motylkowate Drobnonasienne; Biznes-Press: Warszawa, Poland, 2016.

20. Preissel, S.; Reckling, M.; Schläfke, N.; Zander, P. Magnitude and farm-economic value of grain legume pre-crop benefits in Europe: A review. Field Crop. Res. 2015, 175, 64-79. [CrossRef]

21. SBA. Rekommendationer för Gödsling och Kalkning 2017. Jordbruksinformation 24-2016 ("Recommendations for Fertilizing and Lim-ing 2017"); Swedish Board of Agriculture: Jönköping, Sweden, 2016.

22. The Food and Agriculture Organization of the United Nations. International Year of Pulses-Nutritious Seeds for a Sustainable Future; The Food and Agriculture Organization of the United Nations: Rome, Italy, 2016. Available online: http://www.fao.org/pulses-2016 (accessed on 10 May 2020).

23. Dubis, B.; Budzyński, W. Wartość przedplonowa różnych typów łubinu żółtego dla zbóż ozimych (Pre-harvest value of various types of yellow lupine for winter cereals). Rocz. Nauk Rol. Ser. A 1998, 113, 145-154. 
24. European Commission. Report from the Commission to the Council and the European Parliament on the Development of Plant Proteins in the European Union, No. COM(2018) 757 Final; European Commission: Brussels, Belgium, 2018; Available online: https://eur-lex.europa.eu/legal-content/EN/TXT/?uri=CELEX\%3A52018DC0757 (accessed on 1 September 2020).

25. Adams, M.A.; Buckley, T.N.; Salter, W.T.; Buchmann, N.; Blessing, C.H.; Turnbull, T.L. Contrasting responses of crop legumes and cereals to nitrogen availability. New Phytol. 2018, 217, 1475-1483. Available online: https://nph.onlinelibrary.wiley.com/doi/epdf/10.1111/nph.14918 (accessed on 9 September 2020).

26. Jerzak, M.A.; Czerwińska-Kayzer, D.; Florek, J.; Śmiglak-Krajewska, M. Ekonomiczne Determinanty Rozwoju Produkcji i Wykorzystania Rodzimych Roślin Białkowych na cele Paszowe (Economic Determinants of Development of Production and Use of Native Protein Plants for Fodder Purposes); Wydawnictwo Uniwersytetu Przyrodniczego: Poznań, Poland, 2020.

27. FAOSTAT. New Food Balances. Available online: www.fao.org/faostat/en\#data/FBS (accessed on 2 July 2020).

28. Bahl, P.N. Climate Change and Pulses: Approaches to Combat Its Impact. Agric. Res. 2015, 4, $103-108$. [CrossRef]

29. Prus, P. Sustainable Farming Production and its Impact on the Natural Environment-Case Study Based on a Selected Group of Farmers. In Proceedings of the 8th International Scientific Conference RURAL DEVELOPMENT 2017; Aleksandras Stulginskis University: Akademija, Lithuania, 2017; pp. 1280-1285. [CrossRef]

30. Prus, P. The role of higher education in promoting sustainable agriculture, corporate social responsibility and business ethics in the central and Eastern Europe. Nomos Verl. Mbh Co. Kg. J. East Eur. Manag. Stud. (JEEMS) 2019, 99-119. [CrossRef]

31. Łuczka, W.; Smoluk-Sikorska, J. Sustainable consumption-Between theory and practice. In Rural Development 2017: Bioeconomy Challenges: Proceedings of the 8th International Scientific Conference; Aleksandras Stulginskis University: Akademija, Lithuania, 2017; pp. 299-300. [CrossRef]

32. Łuczka, W. Zrównoważona konsumpcja i uwarunkowania jej rozwoju (Sustainable Consumption and Determinants of its Development). Handel Wewnętrzny 2016, 6, 136-145.

33. Neale, A. Zrównoważona konsumpcja. Źródła koncepcji i jej zastosowanie (Sustainable consumption. Sources of concept and implementation). Prace Geogr. 2015, 141, 141-158.

34. Bylok, F. Orientacja prokonsumpcyjna versus orientacja ograniczania konsumpcji we współczesnym społeczeństwie (Consumption orientation versus orientation of limiting consumption in contemporary socjety). Handel Wewnętrzny 2015, 4, 135-144.

35. Wasilik, K. Trendy w zachowaniach współczesnych konsumentów-Konsumpcjonizm a konsumpcja zrównoważona (Trends in the behavior of modern consumers-Consumerism and sustainable consumption). Konsumpcja Rozw. 2014, 1, 66-74.

36. Gerwin, M. Plan zrównoważonego rozwoju dla Polski. Lokalne inicjatywy rozwojowe, Earth Conservation (Sustainable development plan for Poland. Local development initiatives, Earth Conservation). Earth Conserv. Sopot 2008, 1-32.

37. Gill, S. Shopping for Sustainability: Can Sustainable Consumption Promote Ecological Citizenship? Environmental Politics. Available online: Ttps://www.researchgate.net/profile/Gill_Seyfang/publication/ 235356554_Shopping_for_Sustainability_Can_Sustainable_Consumption_Promote_Ecological_ Citizenship/links/5b0d32530f7e9b1ed7fc45ae/Shopping-for-Sustainability-Can-Sustainable-ConsumptionPromote-Ecological-Citizenship.pdf (accessed on 2 July 2020).

38. UNCED (United Nations Conference on Environment and Development). Agenda 21: The United Nations Program of Action from Rio (UN Publications). Available online: http://www.un.org/esa/sustdev/agenda21. htm (accessed on 5 May 2020).

39. Ignatowski, G. Oenzetowskie Szczyty Ziemi a kwestia edukacji ekologicznej (The UN Earth Summit and the Question of Ecological Education). Fam. Pedagog. 2013, 3, 93-109.

40. Sitek, M. The legal and institutional basis for sustainable consumption model in the light of the 7 th Environment Action Programme (EAP) by 2020. J. Mod. Sci. 2014, 23, 231-247.

41. Abdullah, S.N.A.; Chai-Ling, H.; Wagstaff, C. Crop Improvement: Sustainability through Leading-Edge Technology; Springer International Publishing: Cham, Switzerland, 2017.

42. The Food and Agriculture Organization of the United Nations. Sustainable diets and biodiversity: Directions and solutions for policy, research and action. In International Scientific Symposium on Sustainable Diets and Biodiversity: Directions and Solutions for Policy, Research and Action (No. RESEARCH); FAO: Rome, Italy, 2012. 
43. Meulenberg, M.T.G. Consumer and citizen. Meaning for the market of agricultural products and food products. Tijdschr. Soc. Wetens. Onderz. Landb 2003, 18, 43-54.

44. Scholl, G. What is Sustainable Consumption? (Knowledge Base of RESPONDER Project). Available online: http://www.scpresponder.eu/pdf/knowledge/papers/RESPONDER\%20input\%20paper\%20sustainable\% 20consumption.pdf (accessed on 2 May 2020).

45. Roadmap to a Resource Efficient Europe COM 571. Available online: https://eur-lex.europa.eu/legal-content/ EN/TXT/?uri=CELEX:52011DC0571 (accessed on 5 May 2020).

46. Zalega, T. Innowacje a konsumpcja i zachowania konsumentów (Innovations and consumption and consumer behawior). Mark. Rynek 2015, 2, 14-25.

47. Bywalec, C.Z.; Rudnicki, L. Konsumpcja (Consumption); PWE: Warsaw, Poland, 2002.

48. Lorek, S.; Fuchs, D. Sustainable Consumption Governance: A History of Promises and Failures. J. Consum. Policy 2005, 28, 261-288.

49. Lorek, S.; Spangenberg, J.H. Sustainable consumption within a sustainable economy-Beyond green growth and green economies. J. Clean. Prod. 2014, 63, 33-44. [CrossRef]

50. Dabrowska, A.; Ozimek, I. Zrównoważona konsumpcja i produkcja jako atrybut współczesnych społeczeństw i gospodarek. In Ekoinnowacyjność Dziś i Jutro-Wyzwania, Bariery Rozwoju Oraz Instrumenty Wsparcia (Eco-Innovation Today and Tomorrow-Challenges, Development Barriers and Support Instruments); Woźniak, L., Strojny, E., Wojnicka, E., Eds.; PARP: Warsaw, Poland, 2010.

51. Kryk, B. Zrównoważona jakość życia a zrównoważona konsumpcja i zachowania ekologiczne polskich konsumentów (Sustainable Quality of Life vs Sustainable Consumption and Environmental Consumer Behavior). Handel Wewnętrzny 2013, 6, 7-8.

52. Zrałek, J. Dekonsumpcja jako przejaw proekologicznych zachowań konsumentów (Deconsumption as a manifestation of pro-ecological consumer behavior). Handel Wewnętrzny 2012, 2, 135-136.

53. Kramer, J. Konsumpcja-Ewolucja ról i znaczeń. Konsumpcja wobec megatrendów rozwoju społecznego (Consumption-The evolution of roles and meanings. Consumption in the face of megatrends of social development). Konsumpcja Rozw. 2011, 1, 5-15.

54. Kiełczewski, D. Różnorodność stylów życia jako czynnik rozwoju zrównoważonego (The Diversity of Life Styles as a Factor of Sustainable Development). Ekon. Środowisko 2012, 3, 73-84.

55. Górka, K. Zasoby naturalne jako czynnik rozwoju społeczno-gospodarczego (Natural resources as a factor of socialand economic development). Gospod. W Prakt. Teor. 2014, 3, 35-51.

56. Lindgren, E.; Harris, F.; Dangour, A.D.; Gasparatos, A.; Hiramatsu, M.; Javadi, F.; Loken, B.; Murakami, T.; Scheelbeek, P.; Haines, A. Sustainable food systems-A health perspective. Sustain. Sci. 2018, 13, 1505-1517. [CrossRef] [PubMed]

57. Lancaster, K. A New Approach to Consumer Theory. J. Political Econ. 1966, 74, 132-157. [CrossRef]

58. FAO. Guidelines for Assessing Nutrition-Related Knowledge. Attitudes and Practices. KAP Manual. In Manual; FAO: Rome, Italy, 2014.

59. Dobiegała-Korona, B.; Doligalski, T. Zarządzanie Wartościa Klienta: Pomiar i Strategie; Warszawa Pol-tex: Warszawa, Poland, 2010.

60. Gardocka-Jałowiec, A. Zmiany Konsumpcji a Kreowanie Innowacji; Wydawnictwo Uniwersytetu w Białymstoku: Białystok, Poland, 2015.

61. Miczyńska-Kowalska, M. Istota konsumpcji i zachowań konsumenckich-Zarys problematyki (The Essence of Consumption and Consumer Behaviour-An Outline of Problems). Ann. Univ. Mariae Curie Skłodowska Lub. Pol. 2001, 26, 9.

62. Janoś-Kresło, M.; Mróz, B. Konsument i Konsumpcja We Wspótczesnej Gospodarce; Oficyna Wydawnicza SGH: Warszawa, Poland, 2006.

63. Świstak, E.; Laskowski, W. Zmiany wzorca konsumpcji żywności na wsi i ich uwarunkowania (Food consumption changes in rural areas and their determinants). Zesz. Nauk. Szkoły Głównej Gospod. Wiej. Ekon. I Organ. Gospod. Żywnościowej 2016, 114, 5-17.

64. Inglis, V.; Ball, K.; Crawford, D. Does Modifying the Household Food Budget Predict Changes in the Healthfulness of Purchasing Choices Among Low- and High-Income Women? Appetite 2009, 52, $273-279$. [CrossRef]

65. Hulshof, F.K.; Brussaard, J.H.; Kruizinga, A.G.; Telman, J.; Lowik, M.R. Socio-economic status, dietary intake and 10 y trends: The Dutch National Food Consumption Survey. Eur. J. Clin. Nutr. 2003, 57, 128-137. [CrossRef] 
66. Lalukka, T.; Laaksonen, M.; Rahkonen, O.; Roos, E.; Lahelma, E. Multiple socio-economic circumstances and helthy food habits. Eur. J. Clin. Nutr. 2007, 61, 701-710. [CrossRef] [PubMed]

67. Biing-Hwan, L. Nutrition and Health Characteristics of Low-Income Populations: Healthy Eating Index. Agric. Inf. Bull. 2005, 796, 1-4.

68. Mei-Fang, C. Attitude toward organic foods among Taiwanese as related to health consciousness, environmental attitudes, and the mediating effects of a healthy lifestyle. Br. Food J. 2009, 111, 165-178.

69. Goryńska-Goldmann, E.; Ratajczak, P. Świadomość żywieniowa a zachowania żywieniowe konsumentów (Nutritional awareness and nutritional behaviours of consumers). J. Agribus. Rural Dev. 2010, 4, 41-48.

70. Ciati, R.; Ruini, L. Double pyramid: Healthy food for people and sustainable for the planet. In Sustainable Diets and Biodiversity-Directions, Solutions for Policy, Research and Action; Burlingame Band Dernini, S., Ed.; FAO: Rome, Italy, 2012.

71. Macdiarmid, J.; Kyle, J.; Horgan, G.; Loe, J.; Fyfe, C.; Johnstone, A.; Mcneill, G. Livewell: A Balance of Healthy and Sustainable Food Choices; WWF, Rowett Institute of Nutrition and Health, University of Aberdeen: London, UK, 2011.

72. Rejman, K.; Kowrygo, B.; Laskowski, W. Ocena struktury spożycia żywności w Polsce w aspekcie wymogów zrównoważonej konsumpcji (Evaluation of the structure of food consumption in Poland in the context of demands of sustainable consumption). J. Agribus. Rural Dev. 2015, 3, 503-512.

73. Halicka, E.; Kaczorowska, J.; Szczebyło, A. Zrównoważona konsumpcja żywności w wiejskich gospodarstwach domowych z dziećmi (Sustainable Food Consumption in Rural Households with Children). Wieś Rolnictwo 2019, 1, 45-61.

74. WWF-UK, LiveWell for LIFE. The Future of Food-Building the Foundations for Change. Available online: https://livewellforlife.eu/wp-content/uploads/2015/06/LiveWell_Laymans-Report_Final-1.pdf (accessed on 5 August 2020).

75. WWF-UK, Eating for 2 Degrees New and Updated Livewell Plates. Summary, Report. Available online: https://www.wwf.org.uk/eatingfor2degrees (accessed on 5 August 2020).

76. Aleksandrowicz, L.; Green, R.; Joy, E.J.M.; Smith, P.; Haines, A. The impacts of dietary change on greenhousegas emissions, land use, water use, and health: A systematic review. PLoS ONE 2016, 11, e0165797. [CrossRef]

77. Nemecek, T.; Jungbluth, N.; Canals, L.M.; Schenck, R. Environmental impacts of food consumption and nutrition: Where are we and what is next. Int. J. Life Cycle Assess 2006, 21, 607-620. [CrossRef]

78. Hinton, P.R.; McMurray, I.; Brownlow, C. SPSS Explained; Routledge: Abingdon, UK, 2014.

79. Stanisz, A. Przystępny kurs Statystyki z Zastosowaniem STATISTICA.PL; StatSoft Polska: Kraków, Poland, 2007.

80. Główny Urząd Statystyczny. Population, Size and Structure by Territorial Division. Available online: www.demografia.stat.gov.pl (accessed on 10 September 2020).

81. Barrena, R.; Garcia, T.; Sanchez, M. Analysis of personal and cultural values as key determinants of novel food acceptance. Application to an ethnic product. Appetite 2015, 87, 205-214. [CrossRef]

82. Majili, Z.S.; Nyaruhucha, C.; Kulwa, K.; Mutabazi, K.; Rybak, C.; Sieber, S. Preferences and Consumption of Pigeon Peas among Rural Households as Determinants for Developing Diversified Products for Sustainable Health. Sustainability 2020, 12, 6130. [CrossRef]

83. Román, S.; Sánchez-Siles, L.M.; Siegrist, M. The importance of food naturalness for consumers: Results of a systematic review. Trends Food Sci. Technol. 2017, 67, 44-57. [CrossRef]

84. Ronteltap, A.; van Trijp, J.C.; Renes, R.J.; Frewer, L.J. Consumer acceptance of technology-based food innovations: Lessons for the future of nutrigenomics. Appetite 2007, 49, 1-17. [CrossRef] [PubMed]

85. Barska, A.; Wojciechowska-Solis, J. E-Consumers and Local Food Products: A Perspective for Developing Online Shopping for Local Goods in Poland. Sustainability 2020, 12, 4958. [CrossRef]

86. Hamann, K. Innovation and Customer Demand Driving the Food Legume Market. Available online: https://www.true-project.eu/food-legume-market-driver/?fbclid=IwAR0TFQJgb_ LzejwXYCSSRcKSzLMWxLqRjVCJpnvaZAJIOsiZkIMKXt3RaYc (accessed on 12 September 2020).

87. Lea, E.; Worsley, A.; Crawford, D. Australian Adult Consumers' Beliefs about Plant Foods: A Qualitative Study. Health Educ. Behav. 2005, 32, 795-808. [CrossRef] [PubMed]

88. Figueira, N.; Curtain, F.; Beck, E.; Grafenauer, S. Consumer Understanding and Culinary Use of Legumes in Australia. Nutrients 2019, 11, 1575. [CrossRef]

89. Crosland, P.; Ananthapavan, J.; Davison, J.; Lambert, M.; Carter, R. The health burden of preventable disease in Australia: A systematic review. Aust. N. Z. J. Public Health 2019, 43, 163-170. [CrossRef] 
90. Havemeier, S.; Erickson, J.; Slavin, J. Dietary guidance for pulses: The challenge and opportunity to be part of both the vegetable and protein food groups. Ann. N. Y. Acad. Sci. 2017, 1392, 58-66. [CrossRef]

91. Lichtenstein, A.H.; Ludwig, D.S. Bring back home economics education. JAMA 2010, 303, 1857-1858. [CrossRef]

92. U.S. Department of Health and Human Services. Dietary Guidelines for Americans 2015-2020; USDA: Washington, DC, USA, 2015.

93. Malczyk, E.; Kosmaty, I. Preferncje I częstotliwość spożycia potraw z suchych nasion roślin strączkowych wśród wybranej grupy młodzieży. Bromat. Chem. Toksykol 2013, XLVI, 455-461.

94. Soroka, A.; Wojciechowska-Solis, J. Consumer Awareness of the Regional Food Market: The Case of Eastern European Border Regions. Foods 2019, 8, 467. [CrossRef]

95. The Environmental Food Crisis: The Environment's Role in Averting Future Food Crises. A UNEP Rapid Response Assessment. Available online: https://www.unep-wcmc.org/resources-and-data/theenvironmental-food-crisis--the-environments-role-in-averting-future-food-crises (accessed on 5 July 2020).

96. Burgess, M.H.; Miller, P.R.; Jones, C.A. Pulse crops improve energy intensity and productivity of cereal production in Montana, USA. J. Sustain. Agric. 2012, 36, 699-718. [CrossRef]

97. Palmer, S.M.; Winham, D.M.; Oberhauser, A.M.; Litchfield, R.E. Socio-Ecological Barriers to Dry Grain Pulse Consumption among Low-Income Women: A Mixed Methods Approach. Nutrients 2018, 10, 1108. [CrossRef] [PubMed]

98. FAO; WHO. Sustainable Healthy Diets: Guiding Principles; FAO: Rome, Italy; WHO: Rome, Italy, 2019 ; p. 44.

99. Eurostat: Trzy Polskie Region w Grupie Najbiedniejszych w UE, Warszawa—Wśród Najbogatszych. Available online: https://europarlament.pap.pl/eurostat-trzy-polskie-regiony-w-grupie-najbiedniejszych-w-ue-warszawawsrodnaj-bogatszych?fbclid=IwAR3piOk1_uD3FDAUmV1IA0G3go8CcdamnpxjS3x8N0Arwzwa1d968A3HLbw (accessed on 12 September 2020).

100. Wojciechowska-Solis, J. Promotion of local products in regional development, agrarian perspectives XXVII. Food safety-food security. In Proceedings of the 27th International Scientific Conference, Prague, Czech Republic, 19-20 September 2018; pp. 436-442.

101. Sajdakowska, M.; Gutkowska, K. Postawy etnocentryczne konsumentów na rynku żywności. Mark. Rynek 2014, 6, 666-678.

102. Pearson, D.; Henryks, J.; Trott, A.; Jones, P.; Parker, G.; Dumaresq, D.; Dyball, R. Local food: Understanding consumer motivations in innovative retail formats. Br. Food J. 2011, 113, 886-899. [CrossRef]

103. Kostakis, I. The determinants of households' food consumption in Greece. Int. J. Food Agric. Econ. 2014, 2, $17-28$.

104. Melendrez-ruiz, J.; Buatois, Q.; Chambaron, S.; Monnery-patris, S. French consumers know the benefits of pulses, but do not choose them: An exploratory study combining indirect and direct approaches. Appetite 2019, 141, 1-12. [CrossRef]

105. Jallinoja, P.; Niva, M.; Latvala, T. Future of sustainable eating? Examining the potential for expanding bean eating in a meat-eating culture. Futures 2016, 83, 4-14. [CrossRef]

106. Vainio, A.; Niva, M.; Jallinoja, P.; Latvala, T. From beef to beans: Eating motives and the replacement of animal proteins with plant proteins among Finnish consumers. Appetite 2016, 106, 92-100. [CrossRef]

107. Rejman, K.; Kaczorowska, J.; Halicka, E.; Laskowski, W. Do Europeans consider sustainability when making food choices? A survey of Polish city-dwellers. Public Health Nutr. 2019, 22, 1330-1339. [CrossRef]

108. Butu, A.; Brumă, I.S.; Tanasă, L.; Rodino, S.; Dinu Vasiliu, C.; Doboș, S.; Butu, M. The Impact of COVID-19 Crisis upon the Consumer Buying Behavior of Fresh Vegetables Directly from Local Producers. Case Study: The Quarantined Area of Suceava County, Romania. Int. J. Environ. Res. Public Health 2020, 17, 5485. [CrossRef]

109. Katt, F.; Meixner, O. Is It All about the Price? An Analysis of the Purchase Intention for Organic Food in a Discount Setting by Means of Structural Equation Modeling. Foods 2020, 9, 458. [CrossRef] [PubMed]

110. Vinnari, M.; Tapio, P. Future images of meat consumption in 2030. Futures 2009, 41, 269-278. [CrossRef]

(C) 2020 by the authors. Licensee MDPI, Basel, Switzerland. This article is an open access article distributed under the terms and conditions of the Creative Commons Attribution (CC BY) license (http://creativecommons.org/licenses/by/4.0/). 